\title{
Human Capital, Infrastructure and Economic Growth in Nigeria: An Empirical Evidence.
}

\author{
Anochiwa L.I. (Ph.D) $)^{1}$ and Maduka, A (Mrs) Ph.D ${ }^{2}$ \\ Department of Economics and Development Studies, Federal University Ndufu Alike-Ikwo, Ebonyi \\ State, Nigeria. \\ Department of Economics, Anambra State University, Igbariam, Nigeria.
}

\begin{abstract}
Human capital and Infrastructure plays a crucial role in promoting economic growth and thereby contributes to the reduction of economic disparity, poverty and deprivations in a country. Empirically, a variety of studies considers that greater access of the poor to education and health services, water and sanitation, road network and electricity is a principal agent of economic growth. For too long in the past, an undue emphasis has been given to Nigeria's enormous oil resources as a key engine of economic growth. Knowledge capital is fast overtaking physical capital as a determinant of growth. As a fast growing economy Nigeria needs to determine the indices of growth. This study therefore examines the role of human capital and infrastructure on economic growth in Nigeria within a co integration and error-correction modeling framework during the period 1970-2010. Human capital is found to be positive and statistically significant to growth. The infrastructure variable (electricity) is positive but statistically insignificant. This result is not entirely surprising considering the unreliable, epileptic and unstable supply of energy in the country.
\end{abstract}

Keywords: Human capital, Infrastructure, Economic Growth

\section{Introduction}

For too long in the past, economic theories had tended to overemphasize the accumulation of physical capital as a key engine of economic growth and to neglect the significance of the human factor and institutions (ECA, 1995). The argument that human capital play important role in the growth process (notwithstanding the pioneering works of Schultz, 1961a and Becker, 1964), grew out of the Mankiw, Romer and Weil(1992) model where it demonstrated that the 'fit' of the Solow model with the convergence hypothesis could be improved by extending the model to add human capital. Many studies have found a positive relationship between the level of economic development (measured by per capita income and other indicators), and quality of housing and access to basic amenities like electricity, safe drinking water, toilets (SahooPravakar, 2011).

Nigeria is said to be deficient in human capital and infrastructure and as a developing economy, one of the defining features of its growth would be underpinned by the improvement of human capital and massive development of physical infrastructure. Human capital development has been found to play a crucial role in appropriating the gains of foreign direct investment (FDI) with host country and all levels of development especially, in creating the ability to absorb, assimilate and diffuse imported technology. As information grows exponentially, and as its incorporation in the production process becomes increasingly complex, the ability to acquire, adopt and adapt new knowledge becomes an important determinant of economic growth (Isola, 2002). Development of infrastructure (good road network, modern communication, adequate electricity supply, good institutions, water supply, sanitation and sewerage etc.) has been widely cited as a crucial factor in economic growth. Good infrastructure facilitates production, reduces operation costs and increases the productivity of investment and thereby enhances economic growth. It also provides employment opportunities to the poor.Regrettably, what is prominent in the debate of less developed countries (LDCs) is hinged on poor human capital and deficient infrastructure and institutions (Collier et al 1999, Soludo 1998a, 1998), poor economic policies and quality of governance (World Bank, 1989, 1997), and the quality of human development/capacity (UNDP's HDI, ADB 1998).

Infrastructure are public goods and services that goes into the production process as complementary inputs for traditional factors of production such as capital, labour and Entrepreneur. They help to increase returns on investment by reducing production cost and improving transition efficiency. The availability of infrastructure facilities and services as well as the efficiency of such services to a large extent determine the success or otherwise of all other production endeavours. Investments in infrastructures such as energy, water, transportation and communication technologies promote economic growth and help to alleviate poverty and improve living conditions in developing countries (OECD, 2006)

The high cost of education and inadequate investment in infrastructure has made Nigeria to be ranked 158 in the human development and infrastructure index, with value of 0.451 among 187 countries which places her in the bottom of the table. This implies that Nigeria is below the Sub-regions level of human development 
index which is very worrisome. The decay of Nigeria's educational system, coupled with the high cost of schooling and low returns, and the absence of competition in most essential infrastructural institutions, like roads, electricity, sea ports and air ports have put Nigeria on this low scale. The real problem may not be unconnected with continuing government regulations of prices and lack of transparency in privatizing some of the agencies like Power Holding Company of Nigeria (PHCN). Such regulation has proved to be very complex to resolve because of the level of corruption in the country and the leadership that lacks the political will to effect the change.

In explaining the divergence between Nigeria's economic growth and Indonesia, Lewis (2007) said the lack of good institutions has reached an alarming height. "The failure of Nigerian development stems above all from the absence of a political and institutional centre to serve as a principal of economic change". The federal government has boastedby its commitment to the "transformation agenda" to have improved budgetary allocation to the education sector, good as it were, the point to be emphasized is this, "without massive investment in human capital and infrastructure (however defined), Nigeria's participation in the global competition will be a mirage'. An ill-trained, unskilled, unhealthy labour force cannot contribute to or benefit from the Information technology (IT) world(Anochiwa and Nwaogwugwu, 2007).

Most studies in the literature are cross country studies, and cross country studies on public infrastructure investment often ignore thediversity and dynamics that are within each country, despite giving new perspectives and understandings on the role of infrastructure, such as Calderon and Serven (2004). Interestingly, this is a country specific study. Following the claims by the government to have improved budget on education and based on the expected gains of the transformation agenda, it is pertinent to examine the impact of these factors on Nigeria's economic growth. Again, empirical studies on the infrastructure growth nexus in Nigeria are quite limited.

This paper, therefore, builds upon the existing studies on the infrastructure and growth nexus and explores in depth Nigeria's provincial economic growth and the role of infrastructure and human capital. It covers the time span from 1970 to 2010.

\section{Literature Review}

Education is said to be a social process by which individuals are subjected to the influence of selected and controlled environment so as to enable them gain social competence, as well as maximum individual development. Among the developing economies, preference has always been given to simple technology that is amenable to labour-techniques given the abundant labour supply. But developing countries need to possess at least a minimum technological capacity (through technological education) to adapt imported technology (Hayashi, 2002).

For the endogenous growth model, it is investment in human capital that brings about change in total factor productivity (TFP). Earlier models that treat labour as being 'unlimited' are clearly irrelevant today. Labour must be thought in terms of efficiency rather than mere number of people. By providing for enhanced education and improved health, investment in human capital increases the productivity of labour just as surely as does investment that provides additional tools to labour (World Bank, 1980; Stewart, 1987). Serious limitations of human capital and infrastructure are thought to be greater barriers to growth than overall investment levels in many poor countries, especially in the rural sector because poor health and education are such a formidable bottleneck in achieving productivity gains in labour intensive agriculture. The differences in human capital and infrastructure have most probably some of the key factors that widened the gap between African and Asian countries. Recent studies revealed that their exceptional growth can be traced to large increases in measured factor inputs: increases in labor-force participation, increases in the capital stock, and increases in educational attainment (Mankiw, 2003:234).

Some empirical surveys in the literature have attempted to test the influence of human capital input on economic growth. Foster and Rosenzweig (1996) show that more educated farmers are the larger the return to using high-yield variety crops, suggesting that educated farmers are better equipped to take advantage of new technology. In the latter part technology adoption and assimilation, workers need to have a certain level of tertiary education to understand and follow scientific and technological developments available around the world.

Beginning with a cross-country study of per capita GDP growth during two periods (from 1965 to 1975 with 87 countries and from 1975 to 1985 with 97 countries), Barro and Sala-i-Martín (1995) obtained the following findings were, that educational attainment (measured by average years of schooling) is significantly correlated with subsequent growth although if the aggregate measure of educational attainment is decomposed by level of education, the impact of primary education remains largely insignificant; again, public spending on education also has a significantly positive effect on growth: a $1.5 \%$ increase of the ratio of public education spending to GDP during the period 1965-75 would have raised the average growth rate during the same period by $.3 \%$ per year. 
Yet Bils and Klenow (2000) find little evidence that initial schooling affects economic growth sufficiently, and some studies even find negative coefficients on the level of human capital. Contrary to the finding of Bills and Klenow, Tan and Gill (2000) find that in Malaysia, the more educated a worker is, the more likely it is that he or she will receive in-house training, since he or she is likely a better learner than the uneducated worker. It goes without saying that education not only enables workers to learn more efficiently, it also provides them with more frequent opportunities to learn.

Most studies on the infrastructure-economic growth nexus, both at the micro and macro levels, have generally examined and come up with positive indicators of infrastructural development with growth. Drawing inference from the literature review by Antonio Estache and GrégoireGarsous (2012), we see three key infrastructure variables-telecommunication, transport and energy.

\section{i. Telecommunications}

Numerous studies have suggested that infrastructure investment has a tendency to boast economic performance. To many observers, the recent rebasing of Nigeria's GDP can attest to the impact of the telecommunication industry. Telecom alone takes 8.68 percent of the rebased GDP such that the GDP increased from $\$ 262$ billion in 2013 to $\$ 510$ billion. By this development Nigeria becomes the largest economy in sub Saharan Africa. Most studies find a positive impact of telecommunication infrastructure on GDP, on growthand also on labor productivity. Zhan-Wei Qiang and Pitt (2009) and Chakraborty and Nandi (2011), more recent work on the effect of telecom to the GDP has also found positive result. As with other infrastructures, there is a debate on the precise magnitude of its contribution. The IMF has produced a few working papers on the topic. The latest one is by Andrianaivo and Kpodar (2011) focusing on the growth effect of ICT in Africa and it features.

\section{ii. Transports}

For developed countries, the estimated growth effects of transport investments have not been very strong. This is not surprising since their transport stocks are mature. The main impact at advanced stages of development has to come from quality, from addressing bottlenecks or from capturing new network or sup rational effects which have not been internalized in older designs of the transport networks. For developing countries, the picture looks quite different. Whatever is the GDP growth related focus is, most cross-country studies find a positive impact. For instance, roads are needed for Africa to catch with the rest of the world (Buys et al. 2006). Roads are essential to reduce differences across regions within countries (Estache-Fay (2010)). Port quality is central to the evidence collected on the gains from trade facilitation for instance.

\section{iii. Energy}

Among the studies on the importance of access to electricity to human development, those focusing on developing countries all find a positive impact of energy infrastructure on output/growth. In fact, in his survey, Garsous (2012) finds that, ceteris paribus, studies focusing on the energy sector are more likely to find a robust positive impact than any other infrastructure sector. In other words, investing in the energy sector may be the safest bet to achieve a high social rate of return. This should not be a surprise, energy is indeed an input into any of the other infrastructure subsectors - for instance, water is often pumped thanks to electric pumps (Stephane Straub, 2008)

Stiglitz (2006) put it, in the past the hope was that new market access by itself would spur investment in new supply capacity in the LDCs. Time and time again it was, however, learnt that without decent roads, efficient ports, and the technical capability to produce and distribute goods of sufficient quality which collectively called exporting infrastructure, new trading opportunities are meaningless for the poorest countries. In this case, communication services, roads networks, energy sources, schools and health services are some of the key infrastructures required for better FDI inflow.

\section{Model Specification, Estimation and Result.}

Most growth models trace their root to the neo-classical framework of Solow(1956) with later extensions of augmented Solow model (Mankiw and Weil, 1992) and the endogenous growth model. This framework relates output to the factor inputs variables usually referred to as factor productivity. Human capital plays important role in this model. Borrowing from the literature on economic growth, we assumed a neoclassical production function of the form:
$\mathrm{Y}=\operatorname{Af}(\mathrm{K} \mathrm{L})$
eq (1)

Where $\mathrm{Y}=$ output, $\mathrm{L}=$ Labour, $\mathrm{K}=$ capital and $\mathrm{A}=$ technical change variable.

This production function assumes that output depends on capital (both physical and human), labour (both skilled and unskilled) and technical progress. Until the new growth model of Lucas and Paul Romer, physical capital was seen as the major constraint on economic growth among the Less developing countries 
(LDCs). Today it is clear that the world economy is driven by ideas, no wonder human capital, infrastructure, governance and good institutions is seen to play prominent role in economic growth. It will be an error to rely on the two-gap models, a popular development paradigm of the 1950s and 60s, which suggests external borrowing as a source of filling the domestic resource gap.

Borrowing from the Grossman-Helpman (1991) endogenous model and incorporating human capital into the growth process, the production function is written thus;

$$
\mathrm{Y}=\mathrm{K}_{\mathrm{t}} \mathrm{aHB}\left(\mathrm{AL}_{\mathrm{t}}\right) 1-\mathrm{a}-\mathrm{B}
$$

Where $\mathrm{Y}=$ output, $\mathrm{K}$ and $\mathrm{H}=$ aggregate stock of Physical, human and technological capital(R \&D) A and $\mathrm{L}$ are the size of labour force and productivity index which summarizes the state of technical knowledge. Therefore, the starting point of our model specification is depicted with the Grossman-Helpmanmodel, it suggests that a general empirical model of Human capital and Infrastructure on Nigeria's growth could be stated as:

$\mathrm{GDP}=\mathrm{f}(\mathrm{HC}, \mathrm{EG}, \mathrm{INF}, \mathrm{FDI}, \mathrm{CF})$

Note: we have taken into account some other control variables determining economic growth such as physical capital (FDI), domestic capital formation and inflation

Where, GDP = real gross domestic product per capita (proxy for growth); FDI = foreign direct investment; HC $=$ stock of human capital; INF = the rate of inflation; $E G=$ infrastructure development (per capita electricity consumption) Energy; $\mathrm{CF}=$ Domestic capital formation.

\section{Model :}

The linearised version of equation (3) in natural $\log$ form is given as

$\mathrm{InGDP}_{\mathrm{t}}=\varphi_{0}+\varphi_{1} \mathrm{InFDI}_{\mathrm{t}}+\varphi_{2} \mathrm{InINF}_{\mathrm{t}}+\varphi_{3} \mathrm{InHC}_{\mathrm{t}}+\varphi_{4} \mathrm{InCF}_{\mathrm{t}}+\varphi_{5} \mathrm{InEG}+\mathrm{u}_{\mathrm{t}}$

This model was estimated using the co-integration and error correction method (ECM). The data for all the variables of the model were obtained from CBN annual report and statistical bulletin. The period covered is 1970-2010.

Empirical Analysis:In order to test for the stationarity of the variables, Augmented Dickey-Fuller (ADF) tests was used to investigate if the variables had a unit root or not.

Unit Root Test: The Augmented Dickey-Fuller (ADF) test for unit roots was conducted for all the time series employed for the study. The ADF results in Table 1 show that all the variables are non-stationary in their levels. However, with their first differences, growth rate of real GDP, growth rate of FDI, Inflation, human capital and Energy become stationary, that is, they are I(1) since the ADF value of each of these variables are greater than the $5 \%$ critical value in table 2 . With these results, all variables are regressed at their stationary level.

Table 1: Unit Root Test

\begin{tabular}{|l|c|r|}
\hline \multicolumn{4}{|c|}{ Table 4.1: Unit root test result at ordinary level } \\
\hline Variable & ADF statistics & $\mathbf{5 \%}$ critical value \\
\hline LN(GDP) & -0.981791 & -2.9378 \\
\hline LN(FDI) & -0.972888 & -2.9472 \\
\hline LN(INF) & -4.377753 & -2.9378 \\
\hline LN(HC) & -0.502815 & -2.9378 \\
\hline LN(EG) & -2.182604 & -2.9378 \\
\hline LN(CF) & -1.227856 & -2.9378 \\
\hline
\end{tabular}

Table2 : Unit root test result at first difference

\begin{tabular}{|l|r|r|}
\hline Variable & ADF statistics & 5\% critical value \\
\hline LN(GDP) & -4.003169 & -2.9399 \\
\hline LN(FDI) & -8.377755 & -2.9527 \\
\hline LN(INF) & -7.097403 & -2.9399 \\
\hline LN(HC) & -5.3351 & -2.9399 \\
\hline LN(EG) & -6.118468 & -2.9399 \\
\hline LN(CF) & -5.874297 & -2.9399 \\
\hline
\end{tabular}

Table 3: Johanson Cointegration Result model 1

\begin{tabular}{|}
\hline Sample: 19702010 \\
Included observations: 29 \\
\hline Test assumption: Linear deterministic trend in the data \\
\hline \multicolumn{6}{|l|}{ Series: D(LOG(GDP),2) D(LOG(FDI),2) D(LOG(INF),2) D(LOG(HC),2) D(LOG(EG),2) D(LOG(CF),2) } \\
\hline Lags interval: 1 to 1 \\
\hline \multicolumn{7}{|l|}{} \\
\hline \multicolumn{7}{|l|}{} \\
\hline Eigenvalue & Likelihood & 5 Percent & 1 Percent & Hypothesized & No. of CE(s) \\
\hline 0.991984 & Ratio & Critical Value & Critical Value & None ** \\
\hline
\end{tabular}


Human Capital, Infrastructure and Economic Growth in Nigeria: An Empirical Evidence.

\begin{tabular}{|l|c|c|c|c|}
\hline 0.969869 & 339.3892 & 68.52 & 76.07 & At most $1^{* *}$ \\
\hline 0.926732 & 237.8252 & 47.21 & 54.46 & At most $2^{* *}$ \\
\hline 0.890862 & 162.0300 & 29.68 & 35.65 & At most 3** \\
\hline 0.827224 & 97.79094 & 15.41 & 20.04 & At most $4^{* *}$ \\
\hline 0.801376 & 46.87390 & 3.76 & 6.65 & At most $5^{* *}$ \\
\hline *(**) denotes rejection of the hypothesis at 5\%(1\%) significance level \\
\hline
\end{tabular}

Table 4: Parsimonous Error Correction Model 1

\begin{tabular}{|c|c|c|c|c|}
\hline \multicolumn{5}{|c|}{ Dependent Variable: D(LOG(GDP)) } \\
\hline \multicolumn{5}{|l|}{ Method: Least Squares } \\
\hline \multicolumn{5}{|c|}{ Sample(adjusted): 19742010} \\
\hline \multicolumn{5}{|l|}{ Included observations: 32} \\
\hline \multicolumn{5}{|c|}{ Excluded observations: 5 after adjusting endpoints } \\
\hline Variable & Coefficient & Std. Error & t-Statistic & Prob. \\
\hline $\mathrm{C}$ & 0.006088 & 0.012553 & 0.484968 & 0.6347 \\
\hline D(LOG(GDP(-1))) & 0.528104 & 0.161404 & 3.271948 & 0.0051 \\
\hline $\mathrm{D}(\mathrm{LOG}(\mathrm{FDI}))$ & 0.031294 & 0.012849 & 2.435533 & 0.0278 \\
\hline $\mathrm{D}(\operatorname{LOG}(\mathrm{INF}(-1)))$ & 0.065638 & 0.017541 & 3.741907 & 0.0020 \\
\hline $\mathrm{D}(\mathrm{LOG}(\mathrm{HC}))$ & 0.098122 & 0.023170 & 4.234860 & 0.0007 \\
\hline $\mathrm{D}(\mathrm{LOG}(\mathrm{EG}))$ & 0.045520 & 0.043893 & 1.037070 & 0.3161 \\
\hline $\mathrm{D}(\mathrm{LOG}(\mathrm{CF}))$ & 0.056599 & 0.025285 & -2.238421 & 0.0408 \\
\hline $\operatorname{ECM}(-1)$ & -0.492221 & 0.157335 & -3.128479 & 0.0069 \\
\hline R-squared & 0.829684 & Mean D/var & 0.011828 & \\
\hline Adjusted R-squared & 0.648014 & \multicolumn{2}{|c|}{ S.D. dependent var } & 0.081362 \\
\hline S.E. of regression & 0.048271 & \multicolumn{2}{|c|}{ Akaike info criterion } & -2.919177 \\
\hline Sum squared resid & 0.034951 & \multicolumn{2}{|c|}{ Schwarz criterion } & -2.140505 \\
\hline Log likelihood & 63.70683 & \multicolumn{2}{|l|}{ F-statistic } & 4.566982 \\
\hline Durbin-Watson stat & 1.831839 & \multicolumn{2}{|l|}{ Prob(F-statistic) } & 0.002623 \\
\hline
\end{tabular}

$$
\begin{aligned}
& \operatorname{LogGDP}=0.528+0.031 \log \mathrm{FDI}-1+0.0565 \log \mathrm{CF}+0.045 \log \mathrm{EG}+ \\
& * *(3.272) \quad * *(2.435) \quad * *(-2.238) \quad * *(1.0371) \\
& \begin{array}{llll}
(0.005) & (0.027) & (0.040) & (0.316)
\end{array}
\end{aligned}
$$

$0.098 \log \mathrm{HCS}+0.065 \operatorname{logINF}-1.492 \mathrm{ECM}(-1)$
$* *(4.235)$
$* *(3.741)$
$* *(-3.128)$
$(0.000)$
$(0.002)$
$(0.006)$

Note: The Figures in parentheses with double star are the t-statistic. With $\mathrm{df}=26$, the critical value at $5 \%$ significance level 2.056 . So reject null only at $5 \%$ significance level. Reject Ho if $t$-statistic $>$ critical value. TS $>$ CV.

The model was estimated using the co-integration and error correction method (ECM). The data for all the variables of the model were obtained from various issues of CBN annual report and statistical Bulletin, 1970-2010. Most of the variables considered in the determination of economic growth in Nigeria have the expected signs. The coefficient of FDI (a control variable in this context) was expected to be positive and was so. An increase in foreign capital or even domestic capital should impact economic growth positively ( Obwona, 2004; Dike, 2007) .

The value of the adjusted R-squared $\left(\mathrm{R}^{2}\right)$ for the model, is high at $65 \%$. It implies that human capital and infrastructure (Energy) investment and other explanatory variables explained about $65 \%$ systematic variation on Gross Domestic Product (GDP) over the observed period (1970-2010) in Nigerian economy while the remaining $36 \%$ variation is explained by other determinants of growth not included in this study. The value of Durbin Watson is 1.8 for the model. This falls within the acceptable region indicating positive first order serial autocorrelation among the explanatory variables in the model. The F-statistics of 4.5669 is statistically significant at 5 per cent level, indicating that the explanatory variables are jointly significant in influencing Nigeria's economic growth. The Prob(F-statistic) of $0.002<0.05$ at $5 \%$ level is significant which suggests that the model has a very good fit. The lagged error correction term ECM ( $\mathrm{t}-1)$ included in the model to capture the long run dynamics between the co-integrating series are correctly signed (negative) and statistically significant. The coefficient indicated adjustment of $49 \%$ for the model. These adjustments imply that errors are corrected within one year. The error correction model also reveals a long run relationship between explanatory and dependent variables in the model.Thus, the hypothesis of a significant linear relationship between economic growth, measured by the growth rate of GDP, and the five independent variables is validated. 
In examining the relationship between each of the independent variables and economic growth, it could be seen that human capital in particular, had a positive relationship with economic growth. The coefficient of human capital was positive and a one percent increase in human capital development will result to about $9 \%$ increase in growth of GDP. Human capital variable, whose t-statistics is the highest, is positive and statistically significant. The robustness of human capital in the study attests to its importance to the growth of the economy. What is interesting in this survey is that despite the shortfall in Nigeria's development rating it still commands an enviable position in the equation. It goes without saying that if the time and resources spent in seeking for foreign direct investment is channeled towards improving the human capital its growth rate will be higher.

It is observed that infrastructure variable is positive but statistically, insignificant. But this study goes to show that the growth of the economy could seriously be affected and slowed down because of lack of energy. Inadequate electric supply in Nigeria has grown to an alarming rate and each administration that comes into power will put as its primary agenda to fix it. But that it is still positive shows its importance and inevitability in the growth process. That infrastructure matters to growth is now relatively well recognizedand widelyunderstood among economists and policymakers. Infrastructure development contributes to investment and growth through increase in productivity and efficiency as it links between resources to factories, people to jobs and products to markets.

One can also deduce that the availability of infrastructure and human capital is more important to our growth than FDI as adduced by endogenous growth model proponents. In other words, the same zeal expended in luring multinational corporations and their FDI, should be spent in improving our education system and thereby developing the human capital. Again, there is urgent need to revamp and encourage the development of infrastructure. Electricity infrastructure investment seems to play an increasing role in the Nigerian economy even as the enterprise has been privatized. A marginal increase in the growth rate of electricity production per capita is initially associated with a increase in the growth of per capita GDP.

\section{References}

[1]. Aghion, P., \&Howitt, P. (2009). The economics of growth. Cambridge, MA: MIT Press

[2]. Andrianaivo, M. and K. Kodar (2011), "ICT, Financial Inclusion, and Growth: Evidence from African Countries", IMF working papers, WP/11/73, Washington, DC

[3]. Anochiwa L. I and Nwogwugwu, C.C (2007). Skills Acquisition and Employment Generation: Challenges and Strategies. Paper presented to the department of Banking and finance (RIVPOLY) BORI July, 2007.

[4]. Antonio Estache and GrégoireGarsous(2012). The impact of infrastructure on growth in developing countries. IFC Economics Notes. Note 1(April 2012)

[5]. Barro, R. J.; Sala-i-Martín, X. Economic Growth. New York: McGraw-Hill, 1995.

[6]. Becker G.S (1964). Human Capital. A Theoretical and Empirical Analysis with special Reference to Education. New York. Columbia University Press.

[7]. Bils, M., \&Klenow, P. J. (2000). Does schooling cause growth? American Economic Review,90(December (5)), $1160-1183$.

[8]. Buys, P., U. Deichmann and D. Wheeler (2006), "Road Network Upgrading and Overland Trade Expansion in Sub-Saharan Africa", World Bank Policy Research Working Paper No. 4097.

[9]. Chakraborty, C. and B. Nandi (2011), "Mainline telecommunications infrastructure, levels of development and economic growth: Evidence from a panel of developing countries", Telecommunications Policy, 35,441-449

[10]. Collier P and Gunning, J (1999).Explaining African Economic performance.Journal of economic literature ECA, 1995.Human Development in Africa: 1995 Report, Economic Commission for Africa, Addis Ababa.

[11]. Estache, A. and M. Fay (2010) "Current Debates on Infrastructure Policy,” in Globalization and Growth: Implications for a PostCrisis World, Commission on Growth and Development, Edited by Michael Spence and Danny Leipziger, 151-193

[12]. Garsous, G. (2012) “How Productive is Infrastructure? A Quantitative Survey,"ECARES Working Paper, Universitélibre de Bruxelles.

[13]. Hayashi, Mitsuhiro (2002). "The role of sub-contracting in SME development in Indonesia; Micro-level evidence from the metal working and machinery industry.Journal of Asian Economies 13(i). 1-26

[14]. Isola,W.A and Alani, R.A.(2002). Human Capital Development and Economic Growth: Empirical Evidence from Nigeria.Asian Economic and Financial Review.Journal homepage: //aessweb .com/journaldetail.php?d

[15]. Mankiw, N. G., Romer, D. and D. N. Weil, (1992) 'A Contribution to the Empirics of Economic Growth,' Quarterly Journal of Economics, 107, 407-437.

[16]. Mankiw, N.G. (2003). Macroeconomics. New York: Worth Publishers.

[17]. Sahoo, P. and Dash, R.K. (2009). Infrastructure Development and Economic Growth in India,Journal of Asia Pacific Economy, Rutledge 14, 4 p 351-365. Retrieved 21/04/2014

[18]. Sahoo,Pravakar (2011). "Transport Infrastructure in India: Developments, Challenges Lessons fromJapan."Published by Institute of Developing Economies, Japan External Trade Organization (IDE-JETRO), 2011, No.465.

[19]. Schultz, T.W. (1961a). "Investment in Human Capital”. American Economic Review 51: 1-17.

[20]. Soludo, C.C (1998). Trade Policy Reforms and Supply Responses in Africa: .UNCTAD Discussion papers.

[21]. Stephane Straub (2008). "Infrastructure and Development: A Critical Appraisal of the Macro Level Literature.”The World Bank, Policy Research Working Paper 4590, page No.18-1

[22]. Stiglitz, J. 2006. "Aid for Trade." Paper Prepared for the Annual World Bank Conference on Development Economics, Tokyo, Japan, May 29-30, 2006.

[23]. World Bank (1994). World Development Report 1994: Infrastructure for Development. New York: Oxford University Press.

[24]. Zhan-Wei Qiang, C. and A. Pitt (2004): “Contribution of Information and Communication Technologies to Growth," World Bank Publications No. 24. 